Volume 1 Nomor 1

\title{
ADMINISTRASI DAN BIROKRASI PEMERINTAH
}

\author{
Anwar, S.Sos.,M.I.P \\ Alamat email penulis \\ Program Studi Administrasi Publik, Fakultas Ilmu Sosial dan Ilmu Politik, UTB Lampung
}

\begin{abstract}
ABSTRAK
Birokrasi secara umum dapat dibedakan atas tiga bidang, yaitu kelembagaan, prosedur atau tata laksana, dan sumber daya manusia, maka perwujudan reformasi birokrasi juga seharusnya melalui pendekatan dari tiga bidang tersebut. Untuk meningkatkan kemampuan administrasi publik sebagai pelaksana pemerintahan (birokrasi pemerintahan), maka semua unsur birokrat perlu mengkreasi fungsi dan tugasnya dengan ide-ide yang inovatif dalam rangka profesionalitas terhadap pemberian dan penyediaan layanan publik. Oleh sebab itu diperlukan pengetahuan dan pemahaman terhadap esensi publik, baik secara etimologi, pembedaan antara publik dan privat, barang-barang publik maupun perspektif-perspektif publik. Dengan begitu akan adanya sebuah formulasi kolaborasi birokrasi yang, profesional antara prinsip keadilan sosial, efisiensi, prinsip ekonomi dan nilainilainya.
\end{abstract}

Kata Kunci: Reformasi, Birokrasi

\section{PENDAHULUAN}

Bila kita membicarakan birokrasi, maka seharusnya mulailah dari pengertian tentang birokrasi itu sendiri, karena ada ungkapan yang mengatakan kita tahu sesuatu kalau kita melihat dan merasakannya. Orang kebanyakan mengartikan birokrasi adalah sebagai segala sesuatu yang dilakukan oleh pegawai negeri sipil dan segala dampak yang dirasakan oleh masyarakat. Oleh sebab itu hal-hal yang terus paling diingat dibenak mereka adalah hal-hal yang menyangkut perlakukan yang tidak baik (buruk) dan tidak adil dari para birokrat ini. Meskipun kita sadari bahwa tidak semua birokrat yang ada dalam birokrasi publik memiliki perlakuan dan kelakuan seperti yang dibayangkan itu dan kita juga mengetahui bahwa birokrasi itu bukan hanya terdapat pada sektor publik akan tetapi juga terdapat pada sektor swasta, namun karena telah melekat citra buruk pada birokrasi apa lagi dalam konsep birokrasi lahir dari sudut padang yang berbeda-beda, namun intinya pada substansi tidak jauh berbeda, yang pasti dari pemikiranpemikiran tersebut adalah sebuah harapan yang akan menuntun kita untuk berbuat kearah pelaksanaan birokrasi yang lebih baik.

\section{METODE}

Tipe penelitian yang digunakan adalah tipe Kualitatif deskriptif yang dimaksudkan untuk memberikan gambaran secara jelas mengenai masalah-masalah yang diteliti, menginterpretasikan serta menjelaskan data secara sistematis. Dasar penelitian ini adalah survey, yaitu pembagian kuesioner kepada responden yang berisi 
pertanyaan-pertanyaan mengenai hal yang berhubungan dengan penelitian yaitu mengenai Administrasi dan Birokrasi Pemerintah.

\section{ANALISIS HASIL DAN PEMBAHASAN}

\subsection{Birokrasi dan Permasalahannya}

Apabila birokrasi itu memberikan pelayanan publik dengan baik, maka akan terlihat bahwa birokrasi tersebut mampu menunjukkan sejumlah indikasi perilaku sebagai berikut :

1. Memproses pekerjaannya secara stabil dan giat.

2. Memperlakukan individu yang berhubungan dengannya secara adil dan berimbang.

3. Memperkerjakan dan mempertahankan pegawai berdasarkan kualifikasi profesional dan orientasi terhadap keberhasilan program.

4. Mempromosikan staf berdasarkan sistem merit dan hasil pekerjaan baik yang dapat dibuktikan.

5. melakukan pemeliharaan terhadap prestasi yang sudah dicapai sehingga dapat segera bangkit bila menghadapi keterpurukan.

Disebutkkan bahwa tujuan penyediaan birokrasi pemerintahan adalah sebagai berikut :

1. Menyediakan sejumlah layanan sebagai hakekat dari tanggung jawab pemerintah.

2. Memajukan kepentingan sektor ekonomi spesifik seperti pertanian, buruh atau segmen tertentu dari bisnis privat.

3. Membuat regulasi atas berbagai aktivitas privat.

4. Meredistribusikan sejumlah keuntungan seperti pendapatan, hakhak, perawatan medis dan lain-lain.

Namun secara faktual, birokrasi menghadapi sejumlah masalah yang kerap kali menjadi rintangan dalam pelaksanaannya dalam rangka pencapaian tujuan-tujuannya, diantaranya :

1. Proses pekerjaan seringkali tidak dapat diperkirakan dan langkah yang diambil oleh birokrasi juga terkesan lamban.

2. Menunjukkan favoritisme dalam perlakuannya terhadap klien tertentu dan diskriminasi pada yang lain.

3. Memperkerjakan staf yang menunjukkan ketertarikan yang rendah terhadap standar profesional dan kualitas pelayanan program.

4. Mempromosikan staf berdasarkan favoritisme politis atau kriteria yang tidak profesional.

5. Menciptakan timbunan kertas yang tidak berguna dan tidak mampu menyesuaikan diri secara relevan dengan perkembangan sosial.

\subsection{Perjalanan Reformasi Birokrasi di Indonesia dari Waktu ke Waktu}

Reformasi birokrasi di Indonesia telah dilakukan pertama kali pada tahun 1962 (era pemerintahan Soekarno), dengan dibentuknya PRAN (Panitia 
Retooling Aparatur Negara), yang bertugas untuk mengoptimalisasikan fungsi birokrasi dalam penyediaan pelayanan publik. Selanjutnya era Soeharto tahun 1966 yaitu dengan Keputusan Presidium Kabinet Ampera Nomor : 75 yang membentuk Tim PAAP (Tim Penertiban Aparatur dan Administrasi Pemerintahan). Tahun 1974 melalui Kabinet Pembangunan I dibentuknya Kementerian Penyempurnaan dan Pembersihan Aparatur Negara, yang membidangi secara khusus pembenahan administrasi dan birokrasi di Indonesia. Dekade 1980-an hingga awal 1990-an, kita mengenal kebijakan debirokratisasi dan deregulasi yang erat kaitannya dengan menggairahkan investasi modal baik domestik maupun asing. Pada masamasa orde baru pelaksanaan birokrasi jauh dari yang diharapkan (sangat favoritisme dan diskriminatif), karena hampir $80 \%$ Penguasa, Golkar dan ABRI mengendalikan aktivitas masyarakat. Perjalanan orde reformasi berupaya memberikan pencerahan pada setiap aspek dan sektor kehidupan termasuk birokrasi, namun berbagai kendala muncul mulai dari hal-hal yang bersifat politik hingga pada hal-hal yang bersifat praktikal yang menghantarkan kita pada eksistensi konstruksi solusi yang fundamental terhadap permasalahan birokrasi.

\subsection{Redefinisi Reformasi Birokrasi}

Pendefinisian ulang terhadap sebuah permasalahan harus selalu dilakukan, apalagi terhadap informasi mengenai masalah-masalah sosial, sebab informasi masalah sosial terus berkembang seiring dengan perkembangan masyarakat, oleh karenanya permasalahan reformasi birokrasi perlu untuk ditinjau kembali keberadaan masalahnya secara faktual serta kebutuhan pembenahannya dalam porsi yang tepat.

Argumen pelaksanaan reformasi birokrasi salah satunya adalah untuk mewujudkan Good Governance. Good Governance dapat ditinjau sebagai bentuk pergeseran paradigma konsep goverment (pemerintah) menjadi governance (kepemerintahan). Perubahan konsep ini lebih menekankan pada orientasi birokrasi (yang tadinya melayani kepentingan penguasa) sudah saatnya melayani kepentingan publik dengan segala peningkatan baik kuantitas maupun kualitas pelayanan.

\subsection{Pengaruh Political Will} Pemerintah Terhadap Reformasi Birokrasi.

Political will pemerintah dapat menjadi tolok ukur untuk meninjau tingkat keseriusan dalam menjalankan reformasi birokrasi, oleh karena keinginan pemerintah ini mencerminkan pembenahan birokrasi dari dalam tubuh pemerintah itu sendiri, hal ini juga merefleksikan bahwa masalah fundamental dalam tubuh bangsa Indonesia sebenarnya berada di lingkungan birokrasi pemerintahan. Masyarakat pun sudah saatnya ikut mendorong dan turut serta mereformasi birokrasi dengan cara menghilangkan kebiasaan memberikan anggunan, uang 
sogok dan lain-lain, karena hal ini pada dasarnya telah memperparah kondisi patologi birikrasi yang sudah semakin kritis.

\subsection{Dikotomi Politik-Administrasi}

Tujuan pemisahan antara politik dan administrasi pada dasarnya adalah untuk menciptakan birokrat yang profesional dalam memberikan dan menyediakan pelayanan publik tanpa membedakan warna politik warga negaranya.

Muara reformasi birokrasi dalam konteks awalnya adalah optimalisasi penjaringan infilitrasi kepentingan politik dalam ranah administrasi, dimana ranah administrasi merupakan lahan bagi birokrasi melakukan tugas utamanya yakni mengimplementasikan kebijakan. Artinya proses politik cukup terjadi pada saat perumusan kebijakan hingga kebijakan tersebut disepakati. Setelah itu biarkan administrasi melalui instrumen birokrasinya menjalankan tugas sebagaimana mestinya.

\subsection{Reformasi Birokrasi Melalui Revitalisasi Konsep Publik.}

Pandangan dikotomi politik dan administrasi sudah ditepis, karena secara faktual proses politik dan administrasi sulit untuk dipisahkan. Hal yang diperlukan adalah mengkreasi administrasi yang profesional yaitu kemampuan birokrasi untuk tampil prima dalam memberikan pelayanan. Oleh karenanya pendekatan revitalisasi konsep publik sangat dibutuhkan, dan hal-hal yang perlu dikaji secara mendalam bila menggunakan pendekatan revitalisasi konsep publik adalah publik dalam sudut pandang etimologis, publik versus privat, barang publik, dan perspektif publik.

\subsection{Konsep Reformasi Birokrasi yang Ideal}

Dalam kita melakukan reformasi birokrasi, maka kita harus memulainya terlebih dahulu dengan memahami kembali birokrasi dan permasalahanpermasalahannya dan juga melihat perjalanan birokrasi tersebut dari waktu ke waktu. Artinya kita diharuskan memahami perjalanan birokrasi itu dari satu rezim pemerintahan ke rezim pemerintahan berikutnya, hal ini diperuntukkan untuk memperoleh bahan perbandingan tentang apa dan mengapa birokrasi itu dapat berjalan atau tidak dapat berjalan sesuai dengan semestinya, sehingga mendapatkan benang merah dan umpan balik untuk melakukan pembenahanpembenahan terhadap birokrasi itu sendiri pada masa-masa berikutnya. Tujuan yang akan diperoleh apabila kita menengok kembali kebelakang adalah untuk mendapatkan suatu konsep pembenahan birokrasi yang sesuai dan tepat pada porsinya.

Kita sepakat dengan melakukan reformasi birokrasi diawali dengan memahami kembali hakekat dari birokrasi itu sendiri terutama birokrasi publik yang pada notabenenya adalah melayani publik dan penyediaan layanan publik tersebut. Hal yang perlu kita pertanyakan manakala kita melakukan reformasi birokrasi dengan melihat perjalanan rezim pemerintahan yang terdahulu adalah : 
apakah pelaksanaan birokrasi pada pemerintahan yang terdahulu itu tidak baik dan mutlak atas kesalahan pemerintah tersebut? hal ini perlu untuk direnungkan, karena pelaksanaan birokrasi adalah merupakan suatu sistem dari penyelenggaraan pemerintahan yang melibatkan semua unsur penyelenggara pemerintahan yang syarat dengan muatanmuatan kepentingan politik. Oleh sebab itu kita tidak dapat mengkambinghitamkan suatu rezim pemerintahan manakala kita nilai ketidakberesan dari birokrasi. Dengan melihat birokrasi pada rezim pemerintahan yang terdahulu adalah sebagai bahan perbandingan untuk melakukan pembenahan merupakan hal yang wajar dan harus dilakukan, akan tetapi kita juga harus melihat keadaan tersebut secara menyeluruh dan komprehensif, mengingat keadaan sosial masyarakat dulu dan sekarang jauh berbeda.

Reformasi birokrasi yang fundamental adalah dengan cara melakukan redefinisi (pendefinisian ulang) terhadap masalahmasalah birokrasi, karena masalahmasalah birokrasi pada dasarnya merupakan permasalahan sosial yang selalu berkembang seiring dengan kemajuan perkembangan masyarakat. Oleh sebab itu good will pemerintah merupakan kunci yang utama (memiliki peranan penting), perlu dibangun dengan komitmen yang tegas yaitu pembenahanpembenahan sistem regulasi dari dalam (dilingkungan) pemerintahan, karena pada dasarnya masalah birokrasi yang fundamental adalah berada di lingkungan birokrasi pemerintahan. Seiring dengan niat baik pemerintah, maka masyarakat pun akan mengikuti aturan main melalui regulasi-regulasi yang menjadi komitmen bersama, dengan begitu lambat laun pemerintah dan masyarakat akan terbuka sehingga akan tercipta suatu birokrasi pemerintahan yang baik.

Terkait dengan regulasi birokrasi, maka ditekan pada ranah yang jelas dan tegas antara politik dan administrasi publik. Artinya ranah politik dan administrasi publik di lihat dari aspek fungsi dan tugas harus dapat dibedakan, sehingga tercipta birokrasi yang, netralitas dan profesionalitas. Pembedaan dimaksud bukan berarti pemisahan, pembedaan hanya dilakukan untuk memberikan kontribusi fungsi, tugas dan kewenangan masing-masing. Ranah politik cukup pada tatanan proses perumusan kebijakan sampai pada kesepakatan atas kebijakan tersebut, selanjutnya ranah administrasi publik sejatinya melaksanakan kebijakan itu (proses pengimplementasian kebijakan) yang menjadi tugas administrasi publik untuk menuangkannya dalam penyelenggaraan pemerintahan berdasarkan kebijakan-kebijakan yang telah disepakati.

Untuk meningkatkan kemampuan administrasi publik sebagai pelaksana pemerintahan (birokrasi pemerintahan), maka semua unsur birokrat perlu mengkreasi fungsi dan tugasnya dengan ide-ide yang inovatif dalam rangka profesionalitas terhadap pemberian dan penyediaan layanan publik. Oleh sebab itu diperlukan pengetahuan dan pemahaman terhadap esensi publik, baik secara 
etimologi, pembedaan antara publik dan privat, barang-barang publik maupun perspektif-perspektif publik. Dengan begitu akan adanya sebuah formulasi kolaborasi birokrasi yang, profesional antara prinsip keadilan sosial, efisiensi, prinsip ekonomi dan nilai-nilainya.

Bila kita melihat potret birokrasi di Indonesia, ada beberapa hal pokok yang semestinya mendapat perhatian dalam melakukan reformasi birokrasi, karena merupakan hambatan ketidakmampuan birokrasi kita saat ini. Hambatanhambatan ini disebabkan, antara lain :

1. Birokrasi tidak mempunyai tujuan dan misi yang jelas, sehingga tidak mampu memahami aspirasi-aspirasi masyarkat yang dilayaninya. Hal ini terjadi akibat pendidikan dan pengalaman birokrat yang bersangkutan tidak sesuai dengan jabatan dan posisi yang didudukinya. Penempatan dalam jabatan tidak melalui penjaringan yang tepat sesuai dengan kriteria dan sistem yang berlaku dan pendidikan dan pelatihan yang diterima tidak berorientasi pada kepentingan kemasyarakatan.

2. Sruktur organisasi dan kekuasaan tidak berorientasi pelayanan, tetapi berorientasi pada pengaturan dan distribusi, dan dampaknya organisasi yang demikian itu merasa lembaga yang lebih tinggi dari masyarakat, sehingga pelayanan yang diberikan lebih merupakan pemberian atas dasar belas kasihan bukan sebagai kewajiban untuk melayani, pemberian pelayanan yang diskriminatif tergantung pada kedekatan klien.
3. Tidak jelasnya tanggung jawab dan wewenang, sehingga memberikan ketidakjelasan konsekwensi dalam kinerja birokrasi. Kinerja birokrasi tidak nilai berdasarkan bidang tugas dan tanggung jawab, akan tetapi di nilai dari prioritas sektor pada suatu saat dan kedekatannya dengan pimpinan (kekuasaan), baik pada tingkat daerah maupun pusat.

4. Adanya sentralisasi kekuasaan (dalam hal setiap keputusan), artinya setiap keputusan akhir berada pada puncak kekuasaan, hal mengakibatkan mandegnya kreasi dan kreatif sebagai dasar inavatif bagi birokrat dan menimbulkan berbagai penyimpangan.

5. Adanya budaya formalisme dan simbolisme dalam masyarakat, akibatnya semua masalah dihadapi dan ditangani dengan semboyan dan pernyataan tekad saja tidak ada penanganan secara riil dan proporsional.

Oleh karena birokrasi secara umum dapat dibedakan atas tiga bidang, yaitu kelembagaan, prosedur atau tata laksana, dan sumber daya manusia, maka perwujudan reformasi birokrasi juga seharusnya melalui pendekatan dari tiga bidang tersebut.

1. Dari segi bidang kelembagaan

a. Perlu adanya lembaga yang efisien dan efektif, yaitu lembaga yang berorientasi pada tugas dan tanggung jawab yang jelas. Tidak dibentuk sekadar untuk mengakomodasi personil yang berlebihan. Lembaga 
tidak diadakan jika tidak ada tugas dan tanggung jawab yang jelas, jumlah yang melayani di lapangan lebih banyak dan mempunyai tanggung jawab tersendiri.

b. Lembaga bersifat terbuka terhadap laporan dan pengaduan masyarakat pada tingkat yang terendah dan menengah. Untuk itu harus disediakan saluran penampungan keluhan dan saran dari pegawai (bawahan) tentang berbagai keperluan dan kelemahan.

c. Sejauh mungkin dihilangkan monopoli kekuasaan, dengan membuka kemungkinan pelayanan tidak hanya pada satu tempat.

2. Dari segi prosedur atau tata laksana.

Prosedur atau tata laksana tidak berbelit-belit, mudah dan cepat dalam melayani dan menampung serta menyalurkan aspirasi masyarakat.

a. Pelayanan bersifat terbuka untuk semua pihak yang berhak dan terbuka terhadap penilaian.

b. Setiap saat ada penilaian sesuai dengan kebutuhan dan keluhan yang diterima.

c. Tarif pelayanan semurah mungkin dan mudah dijangkau dari berbagai tempat dalam sesuatu lokasi dan wilayah.

3. Dari segi sumber daya manusia.

Pengadaan personalia harus benarbenar dilakukan secara objektif dan terbuka. Demikian juga dalam penempatan dan pengembangan.

a. Penerapan merit sistem harus dilakukan secara konsekwensi, objektif, jelas dan tegas. b. Pendidikan dan pelatihan didasarkan pada kesadaran mengenai kebutuhan pelayanan dan pembangunan dalam masing-masing bidang. Pendidikan dan pelatihan relevan dengan fungsi dan tugas aparatur.

c. gaji yang dibayar cukup untuk menjamin kehidupan yang layak. Dengan demikian menjadi pegawai negeri merupakan pilihan yang layak bagi orang-orang yang jujur.

Singkatnya, jika kita ingin melakukan reformasi birokrasi, prioritas pertama harus meliputi kelembagaan, prosedur atau tata laksana dan sumber daya manusia.

Khusus pada sumber daya manusia (aparatur pemerintah) pelaku birokrasi, perlu diperhatikan kesejahteraannya. Sejauh ini perhatian kesejahteraan terhadap aparatur pemerintah (PNS) tidak memiliki dasar yang komprehensif, kebijakan-kebijakan yang dilakukan selama ini hanya bersifat reaktif semata. Kesejahteraan birokrat publik meliputi hak-hak yang harus didapatkan oleh birokrat publik termasuk didalamnya adalah gaji dan berbagai tunjangan atau benefit lainnya. Di Indonesia disamping sistemnya yang perlu diperbaiki, tetapi juga diakibatkan belum sejahteraannya para birokrat publik ini. Kesejahteraan tidak harus diartikan dengan gaji, gaji hanyalah salah satu alat untuk meningkatkan kesejahteraan birokrat. Gaji sebagai alat untuk meningkatkan kesejahteraan birokrat publik telah mengakibatkan efek psikologi terhadap ekonomi makro di Indonesia. Hal ini 
terjadi karena selama beberapa dekade, masalah kenaikan gaji telah menjadi komoditi politik. Akibatnya kenaikan gaji yang diumumkan empat bulan sebelumnya (bersamaan dengan penyampaian nota keuangan pemerintah) sebesar $10 \%$ misalnya telah mengakibatkan kenaikan kebutuhan pokok lebih dari $10 \%$ pada bulan pengumuman itu. Akibatnya empat bulan kemudian ketika gaji yang telah naik itu, daya beli birokrat publik tidak bertambah baik.

Kesejahteraan birokrat dapat dilakukan dengan diawali oleh perbaikan struktur gaji minimal dan maksimal serta perbedaan untuk setiap level, kemudian menetapkan kenaikan berkala yang cukup memadai tanpa harus diumumkan apalagi dipolitisasi. Dan yang penting adalah penyediaan berbagai jaminan atau asuransi bagi para birokrat, jaminanjaminan ini pada gilirannya akan membuat para birokrat bekerja dengan tenang dan produktifitas yang tinggi. Jaminan-jaminan yang paling pokok antara lain :

1. Jaminan pendidikan bagi anak-anak sampai dengan tingkat sekolah menengah atas.

2. Jaminan pelayanan kesehatan.

3. Jaminan pemilikan tempat tinggal.

4. Jaminan hari tua

Jaminan-jaminan tersebut pada beberapa bagian bukanlah hal yang baru, namun perlu diperbaiki dan ditingkatkan. Misalnya jaminan untuk pelayanan kesehatan yang dikenal dengan asuransi kesehatan (ASKES dan apapun sebutan lainnya), mestinya bagi para birokrat dapat menggunakannya ditempat perawatan manapun dengan batasan yang manusiawi.

Dengan menerapkan sistem jaminan ini bagi peningkatan kesejahteraan para birokrat, maka beban terhadap anggaran negara tidak akan sebesar apabila jaminan itu disediakan sendiri oleh pemerintah, pemerintah cukup mensubsidi premi atas jaminan itu, atau bahkan bisa saja dipotong dari gaji yang bersangkutan setelah struktur gajinya diperbaiki.

\subsection{Hambatan}

Harapan dalam melakukan reformasi birokrasi sebagaimana yang diuraikan di atas sangat baik dalam menuju birokrasi yang ideal, namun perlu kita camkan bahwa pembenahan birokrasi yang demikian itu sangatlah riskan dan jauh dari harapan bila melihat penyelenggaraan birokrasi di Indonesia.

Bila dilihat dari level (wilayah pembenahan birokrasi) adalah secara menyeluruh atau boleh dikatakan bahwa ajakan pembenahan birokrasi (reformasi birokrasi) menurut Kristian Widya Wicaksono merupakan revolusi birokrasi dan ini akan sulit terwujud, mengingat bangsa Indonesia yang beraneka ragam, pluralis namun telah tertanam nilai-nilai Pancasila dan Undang-Undang Dasar 1945 yang menjadi dasar dalam penyelenggaraan birokrasi pemerintahan, disamping itu patologi birokrasi yang semakin kritis sangat memerlukan pembenahan-pembenahan secara tepat, cepat dan selektif. 
Volume 1 Nomor 1

Walaupun keberadaan birokrasi itu hampir seumur dengan keberadaan peradaban manusia, namun sangatlah meluas apabila kita akan melakukan reformasi birokrasi secara menyeluruh dari semua aspek. Namun seperti yang telah dikemukakan di atas, bahwa kita juga tidak dapat memungkiri suatu keuntungan yang akan diperoleh apabila reformasi birokrasi yang diharapkan itu dapat terwujud di Indonesia adalah akan membentuk kemandirian, terbentuknya kepercayaan diri dan kejujuran yang bersumber dari dalam (birokrasi pemerintahan).

\begin{tabular}{lcr}
\multicolumn{1}{c}{ Birokrasi } & pada & hakekatnya \\
merupakan & suatu & sistem \\
penyelenggaraan & pemerintahan & sebuah
\end{tabular}
negara. Suatu negara berdiri atas dasar dan azas yang disepekati. Di Indonesia penyelenggaraan pemerintahan berdasarkan Pancasila dan UndangUndang Dasar 1945, oleh sebab itu melakukan reformasi birokrasi yang sifatnya revolusi birokrasi tentu akan terbentur dengan nilai dan semangat Pancasila dan Undang-Undang Dasar 1945 yang dijadikan landasan, pedoman dalam penyelenggaraan pemerintahan (birokrasi) di Indonesia. Masalah birokrasi adalah masalah sosial, oleh karenanya reformasi birokrasi cukup dengan melakukan tuntutan reformasi birokrasi yang responsif yang mampun menampung aspirasi dan tuntutan masyarakat dan menyalurkan aspirasi tersebut kepada pihak yang bertanggung jawab membuat kebijakan. Selanjutnya menterjemahkan kebijakan pemerintah kepada masyarakat sesuai dengan aspirasi dan nilai-nilai yang berlaku. Hambatan yang timbul adalah manakala birokrasi itu tidak mampu menampung dan menyalurkan aspirasi masyarakat, dan tidak mampu menterjemahkan kebijakan-kebijakan pemerintah ke dalam bahasa masyarakat dan lingkungan. Hambatan-hambatan ini terjadi pada birokrasi pemerintahan Indonesia saat ini.

\section{PENUTUP}

\section{Simpulan}

$$
\begin{aligned}
& \text { Berdasarkan uraian-uraian } \\
& \text { Administrasi dan } \\
& \text { Pemerintahan pada sub bab Reformasi } \\
& \text { Birokrasi, maka dapat disimpulkan hal- } \\
& \text { hal sebagai berikut: }
\end{aligned}
$$

1. Dalam melakukan reformasi birokrasi dimulai dari pemahaman kembali tentang birokrasi dan permasalahannya, mencari umpan balik terhadap penyelenggaraan birokrasi pada masa pemerintahan yang terdahulu dengan mendefinisi ulang permasalahan-permasalahan sosial, niat baik (political will) pemerintah dijadikan sebagai tolok ukur, penempatan ranah politik dan ranah administrasi sesuai pada fungsi dan tugasnya, revitalisasi konsep publik melalui pendekatan etimologi, pembedaan konsep publik dan privat, pendekatan barang publik dan pendekatan perspektif publik.

2. Melakukan reformasi birokrasi tidak harus dengan revolusi birokrasi, namun harus lebih tepat, cepat dan selektif. 


\section{Saran}

1. Sebaiknya melakukan reformasi birokrasi ditekan pada hal-hal yang memang perlu untuk dibenahi (artinya tidak semua aspek/unsur birokrasi dipangkas habis, tidak harus secara radikal atau revolusioner), sehingga substansi pembenahan dapat dikontrol.

2. Karena birokrasi secara umum meliputi tiga bidang yaitu kelembagaan, proseudr atau tata laksana dan sumber daya manusia, maka melakukan reformasi birokrasi, prioritas pertama harus meliputi tiga bidang tersebut (kelembagaan, prosedur atau tata laksana dan sumber daya manusia).

\section{DAFTAR BUKU}

Kristian Widya Wicaksono, 2006, Administrasi dan Birkorasi Pemerintah, Graha Ilmu Yogyakarta. 